Scientific journal

PHYSICAL AND MATHEMATICAL EDUCATION

Has been issued since 2013.

Науковий журнал

ФІЗИКО-МАТЕМАТИЧНА ОСВІТА

Видається з 2013.
ISSN 2413-158X (online)

ISSN 2413-1571 (print)

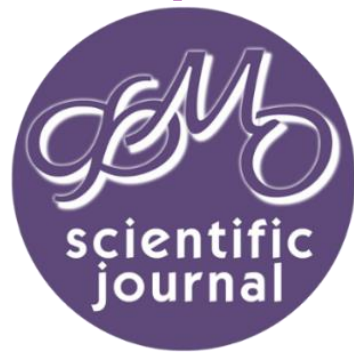

Білоусова Л.І., Гризун Л.Е. Використання компютерних моделей в умовах реалізації цілісного підходу до навчання математики в школІ. Фізико-математична освіта. 2019. Випуск 1(19). С. 7-12.

Bilousova L.I., Gryzun L.E. Computer Models Using In Terms Of The Realization Of Holistic Approach To School Mathematics Learning. Physical and Mathematical Education. 2019. Issue 1(19). P. 7-12.

DOI 10.31110/2413-1571-2019-019-1-001

UDK 371.67

L.I. Bilousova

Kharkiv National Pedagogical University named after G.S. Skovoroda, Ukraine lib215@gmail.com

ORCID: 0000-0002-2364-1885

L.E. Gryzun

Kharkiv National Pedagogical University named after G.S. Skovoroda, Ukraine lgr2007@ukr.net

ORCID:0000-0002-5274-5624

\title{
COMPUTER MODELS USING IN TERMS OF THE REALIZATION OF HOLISTIC APPROACH TO SCHOOL MATHEMATICS LEARNING
}

\section{ABSTRACT}

Analysis of the problems of contemporary mathematical education reveals necessity of improvements of the learning approaches. Being complicated integrative science, Mathematics nowadays tends to become a bridge between various subject areas, which causes greater importance of deep understanding of mathematical basics. On the other hand, learning Mathematics appears to be really complicated for schoolchildren, as it operates by the system of concepts with high level of abstraction.

Formulation of the problem. Thus, according to the studies, it seems to be necessary to implement holistic educational ideas into Mathematics teaching. It can help to form students' concentrated conceptual mathematical knowledge and facilitate their using. However, in order to apply effectively holistic approach we need to arm teachers with proper didactic aids. On balance, computer models development and their implementation for holistic learning of mathematical objects seem to be vital for contemporary education. The aim of the paper is to represent the authors' complex of computer models and their didactic facilities as for the abstract mathematical concepts mastering by schoolchildren. It is also covered the role of the models and recommendations for their classroom using in terms of holistic approach to school Mathematics learning.

Materials and methods. Analysis of the number of studies enables us to cover theoretical basics as for the peculiarities of mathematical objects mastering by students, the difficulties which might happen during their learning, and instruments that can facilitate them. During the research, the set of theoretical, empirical, and modelling methods were applied. Theoretical background for the computer models elaboration made comprehensive analysis of the current mathematical curriculum, demands to the final requirements to the pupils' knowledge and skiils, and learning of related subject areas, held by the authors beforehand. In order to meet the main principles of holistic approach to mathematical education it is also necessary to reveal key mathematical objects, establish connections between them, and build chains of proper internal and transdisciplinary links.

Results. The results of the theoretical analysis were used at the design of the authors' complex of computer models which can be implemented in terms of the realization of holistic approach to school Mathematics learning. The complex of the computer models embraces some groups of models directed on the facilitating the mastering of a number of abstract mathematical concepts. The process of the models elaboration is covered in the paper as well as the models functionality and didactic support to them. The potential of the elaborated complex of computer models as for their implementation in terms of holistic approach to Mathematics school learning is proved and analyzed.

Conclusions. It seems to be relevant to predict positive influence of the computer models implementation on the forming of trainees' holistic system of knowledge and skills. Elaboration of proper methodology of its diagnosing and estimation might be a prospect of our further research.

KEY WORDS: holistic approach, mathematical education, computer models, school Mathematics learning, abstract concepts mastering, didactic facilities of computer models.

\section{INTRODUCTION}

Nowadays national and global education is experiencing the period of various transformations, which can be explained by number of objective reasons, such as globalization processes, integrative trends in science and education, rapid increase of knowledge amount, etc. It is clear that under the circumstances, conventional educational paradigm tends to be changed with 
different approaches (and their combinations) to teaching and learning. Recently, it has been developing holistic educational approach which concentrates on creating coordinated and interconnected pedagogy [8].

At the same time, analysis of the problems of contemporary mathematical education $[2 ; 4 ; 10]$ reveals necessity of improvements of the learning approaches. Being complicated integrative science, Mathematics nowadays tends to become a bridge between various subject areas, which causes greater importance of deep understanding of mathematical basics. On the other hand, learning Mathematics appears to be really complicated for schoolchildren, as it operates by the system of concepts with high level of abstraction.

Thus, according to the studies [ $4 ; 14$ and others], it seems to be necessary to implement holistic educational ideas into Mathematics teaching. It can help to form students' concentrated conceptual mathematical knowledge and facilitate their using. However, in order to apply effectively holistic approach we need to arm teachers with proper didactic aids.

On the other hand, computer technologies grant their powerful facilities of modelling, which can be used to facilitate implementation of holistic educational approach [10;11; 12].

On balance, computer models development and their implementation for holistic learning of mathematical objects seem to be vital for contemporary education.

The aim of the paper is to represent the authors' complex of computer models and their didactic facilities as for the abstract mathematical concepts mastering by schoolchildren. It is also covered the role of the models and recommendations for their classroom using in terms of holistic approach to school Mathematics learning.

\section{THEORETICAL BACKGROUND}

Analysis of the number of studies $[1 ; 4 ; 5 ; 7]$ enables us to cover theoretical basics as for the peculiarities of mathematical objects mastering by students, the difficulties which might happen during their learning, and instruments that can facilitate them. According to researchers, Mathematics as a curriculum discipline operates with the complex of learning elements which have really complicated nature. On the one hand, they are mental forms that help to distinguish them from other concepts. On the other hand, mathematical concepts stand for abstractions of numerical relations, space representation of real objects etc.

In scientific papers it is also pointed out that mathematical objects (concepts, theorems, rules, algorithms etc.) are strongly connected both with each other and with non-mathematical objects. They form in such a way a network with numerous links which reflect the structure of mathematics. This structure can be shown as a graph where nodes represent mathematical and non-mathematical objects (components), and edges reflect relations on them. It is also emphasized that this is the reason why it is really complicated for pupils to grasp mathematical knowledge and integrate it into their own minds [1].

In addition, all mathematical objects have peculiarities of their perception and mastering by trainees which are vital to bear in mind for educators. In particular, concepts must be formed on different levels of their understanding and has to be applied to various kinds of activity: from using in theorems to practical tasks solving. At theorems introducing, it is important to motivate trainees to analyze the sense of the proposition and find relations to known concepts, theorems, rules etc. In the process of learning the theorem proof, researchers recommend to concentrate on the proof search and conclusions argumentation. Algorithms mastering as an element of educational content expects revealing of the sequence of operations, their analysis, establishing links with other elements of knowledge etc.

On the other hand, mathematics is considered to be instrumental and outlook base for learning many other disciplines. That means that the pupils' holistic perception of the world depends on their success in mastering mathematics and understanding the mathematical interpretation of the various phenomena.

Thus, these peculiarities determine features of trainees' activity on the mathematical content mastering, and at the same time direct the teachers' work. According to the studies, doing Mathematics, the trainees have to perform the set of complicated actions such as: taking in abstract concepts, establishing causal relationships within mathematical facts, revealing aspects of abstract and real objects, dividing them into parts, constructing, determination of sequence of procedures and their implementation etc.

In the terms of conventional approach to teaching and learning, these activities can cause significant trainees' difficulties, which can not contribute to proper understanding of mathematical objects. It might also result in the formation of poor base for other disciplines learning, lack of integrated knowledge and skills. However, nowadays holistic approach to Mathematics education is being elaborated, which can be characterized as a comprehensive paradigm that promotes the cohesive development of the whole child at the intellectual, physical and emotional levels [13; 14]. More over, children are encouraged to apply mathematical skills to daily real-life tasks and their activity in the fields of their interests.

Analyzing basic principles of holistic paradigm (in particular, [8; 9]), we could distinguish several ones which seem to be significant in terms of exactly mathematical education. The first principle focuses on the students' freedom and autonomy, which means that a pupil is considered to be an active participant of the cognitive activity who interacts with science and reality via his own actions, manipulations and experience.

Next important pillar of the holistic approach is necessity to establish links and relationships between the object of learning and existing knowledge. The more connections trainees have, the stronger memories are formed in their minds and better understanding of the whole they obtain. As it was mentioned earlier, making right connections by students means realizing how mathematical objects are linked to each other and how they match to the real objects as well as to the concepts of other branches of science.

Transdiciplinarity pillar also means links making, but it rather focuses on ruining boundaries between Mathematics and other subject fields as well as between Mathematics and reality in the process of teaching and learning. Thus, such an approach gives trainees understanding how mathematical objects work together and how they unite other subject areas.

The analysis of peculiarities of Mathematics as a curriculum discipline and holistic approach to its learning testifies a need to apply efficient didactic aids which enable to facilitate the learning and teaching processes.

One of such tool seems to be computer models. Models application to Mathematics mastering adjusts with theory of generic models which decomposes the cognitive process into the levels of generalization and abstraction and focuses on the manipulations with the basic model of some mathematical object [5-7]. According to the researchers, at the generalization level, where students work independently with the model (as an image of a mathematical object), their minds build the chain: 
experiences $\rightarrow$ generalization $\rightarrow$ basic model. At the abstraction level, when students' are offered the set of key tasks with the model, it loses its direct association with specific object and transforms into abstract knowledge whose structure is richer than that of the basic model. In such a way it is built the chain: basic model $\rightarrow$ abstraction $\rightarrow$ abstract knowledge.

An analysis of the trainees and teacher's activities in the implementation of holistic approach to mathematics learning testifies that for its support a significant role can be played by exactly computer dynamic models. They can be attributed to educational software, which represents a model of the system under the changes caused by some events in real time, by the movement of objects in space etc. These aids must meet the requirements of scientific nature, accessibility, visibility, practical application, etc. It is important to underline that the requirement of visibility in terms of holistic mathematical education must be considered not only as a possibility to visualize mathematical objects for trainees' passive contemplation, but rather as an advantage to provide active transforming activity in which the students independently build models or manipulate with them. After analyzing computer models, establishing significant links between their components, highlighting certain signs, pupils will be able to form and develop techniques of mental activity $[10 ; 11 ; 12]$.

Key didactic tasks with computer models must be characterized as those which encourage trainees' mental activities; are focused on the reality of the cognitive situation; have research purposes on the basis of modeling; generate conditions for trainees' awareness of the contradiction between known and unknown etc. The tasks performed with computer models very often include computational experiments at the formation of fundamental abstract concepts. It enables to obtain their visual interpretation, to verify known propositions, to realize them deeper via active manipulations and changes of the model parameters [10; 15].

\section{METHODS OF RESEARCH}

During the research, the set of theoretical, empirical, and modelling methods were applied. Theoretical background for the computer models elaboration made comprehensive analysis of the current mathematical curriculum [3], demands to the final requirements to the pupils' knowledge and skiils [2], and learning of related subject areas, held by the authors beforehand. In order to meet the main principles of holistic approach to mathematical education (covered earlier) it is also necessary to reveal key mathematical objects, establish connections between them, and build chains of proper internal and transdisciplinary links. The detailed process of models building is covered below.

\section{RESULTS OF THE RESEARCH}

The results of the theoretical analysis were used at the design of the authors' complex of computer models which can be implemented in terms of the realization of holistic approach to school Mathematics learning.

The process of the models elaboration covers some phases. At the first step, mathematical model of the future computer model is created. At this point it is provided: (1) revealing the essence of the proper concept, its links with other mathematical and non-mathematical objects; (2) defining of the dependencies which enable to illustrate and explore the concept; (3) revealing the fixed and changeable model parameters along with the range and step of their altering; (4) picking up proper graphic elements which are able to visualize dynamic changes; (5) thinking over the tasks which are relevant to solve using the model.

At the second phase the mathematical model is transformed into computer one by the means of the MS Excel and VBA programming language. The table of values of the functional dependencies with references to the cells with variable parameters are built. Their original values are set. Necessary charts and their elements are built. Proper control elements are created on the worksheet and the algorithm of actions that must be implemented when manipulating control elements is developed. Then proper VBA procedures are elaborated.

The next phase is devoted to the testing, debugging and improving of the model.

The fourth phase of the models creation is focused on the development of didactic support for the implementation of the holistic approach to mathematical education which includes the set of specific tasks for trainees: (1) the scheme of work with the model, aimed at grasping the essence of the concept as well as the the scheme of the computing experiment are determined; (2) it is found out what learning material should be offered as an explanation, what heuristic questions should be asked, how to summarize the results of work with the model etc; (3) the developed didactic support is included into the MS Excel worksheet using special controls elements (command buttons that call the windows with the required text fields, buttons and other interface elements); 4) the interface of the model is adjusted.

The final stage of the development of computer models is devoted to their testing and analysis of the results of their implementation.

The complex of the computer models embraces some groups of models directed on the facilitating the mastering of a number of abstract mathematical concepts.

The first group includes the models (Models 1-3) which are aimed at the understanding the essence of the derivative concept, its relations to the limit notion, its geometric and physical interpretation. There are the models like "Motion in a straight line: instantaneous velocity", "Motion under the influence of gravity", and "Motion of the point along the curve: positions of the secant and tangent lines. Derivative").

Let us describe the work with the model "Motion in a straight line: instantaneous velocity" as an example of the models implementation. Using the tools of the model, the pupil is able to direct $\Delta t$ to 0 and observe how, with decreasing $\Delta t$, the distance $\Delta \boldsymbol{S}$ decreases and directs to the value $\boldsymbol{S}=\boldsymbol{F}(\boldsymbol{t})$. As a result of manipulating the instruments of the model and answering the proposed questions from didactic support, the student is encouraged to make the conclusion that the instantaneous velocity of a traveler, who is moving along a straight-line road, at the moment of time $\boldsymbol{t}$ is naturally to be defined as the limit of the ratio of path increment to the increment of time when it goes to 0 . The episodes of pupils' work with the model "Motion in a straight line: instantaneous velocity" and its didactic support is shown on the Figure 1.

Similar didactic support stimulates pupils to manipulate with other models of the first group. It enables them to understand that all the considered examples of the motion leads to a mathematical operation that must be performed with the function to find the instantaneous speed of its change (velocity of a traveler motion, speed of the body at falling, speed of 
changing of the amount of electricity, etc.). This operation is the finding the limit of the ratio of path increment to the increment of time when it goes to 0 . Thus, in such a way pupils obtain deep and holistic understanding of the derivative concept along with the links with other mathematical and non-mathematical objects.

The following group (Models 4-5) is devoted to the study of the concepts of continuity and discontinuity of the function, awareness of the conditions of continuity of the function. Two functional dependences at different intervals of the argument value are used to build the models. With the help of the model "Continuity of the function" students are encouraged to make a conclusion as for the connection between function continuity and having its derivative at a point. Also the set of tasks of the didactic support helps to realize the reasons of the function discontinuity. The episodes of pupils' work with the models $4-5$ and their didactic support is shown on the Figure 2.
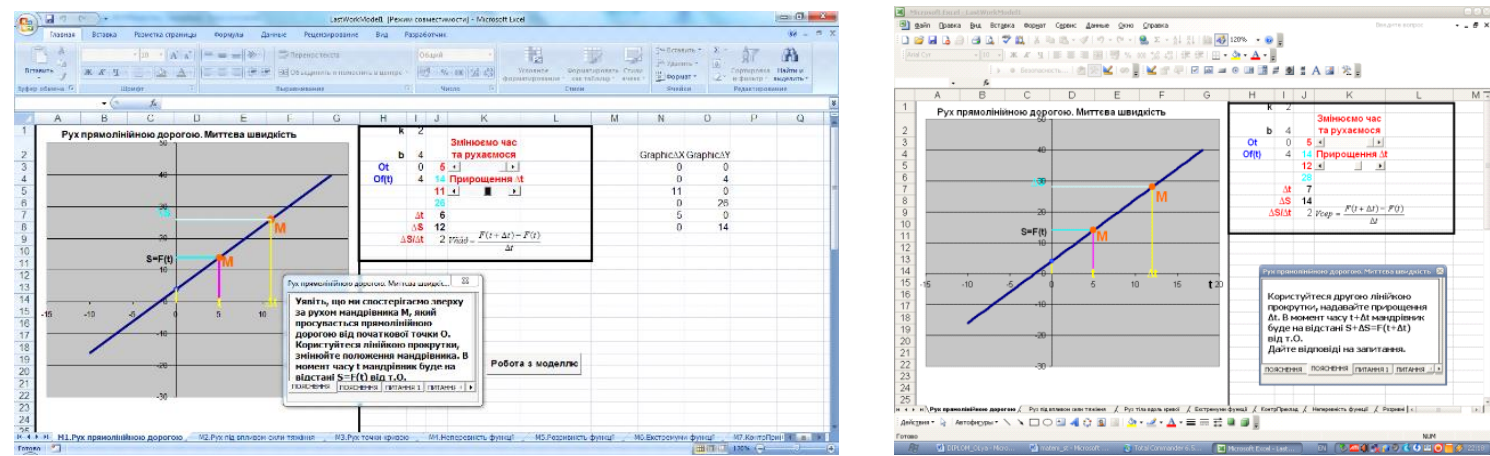

Fig. 1. The episodes of pupils' work with the model "Motion in a straight line: instantaneous velocity"
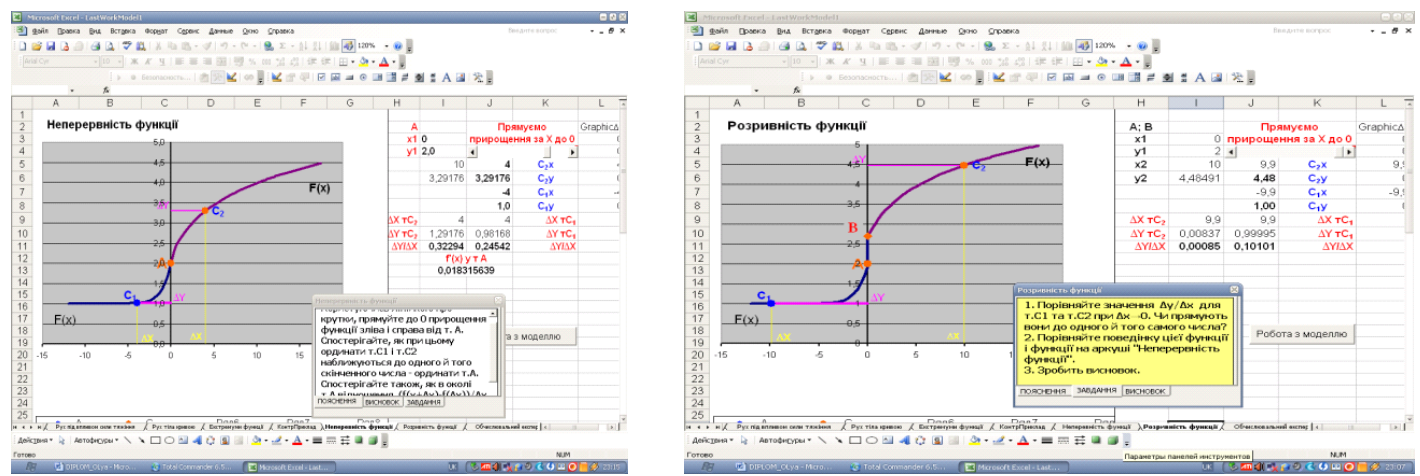

Fig. 2. The episodes of pupils' work with the models "Continuity of the function" and "Discontinuity of the function"

Models 6-7 serve to solve a range of research tasks. They can be used to study simultaneously the growth and decrease of a function, the behavior of the tangent to the curve when passing via the points of maximum and minimum of the function, and the necessary and sufficient conditions for the extremum existence. The work with the complex Model 6 ("Extremums") can be organized as a set of tasks similar to the following ones.

Task 1. 1) Give the definition of ascending and descending functions; 2) Use the scroll bar to give $\boldsymbol{X}$ a positive increment. Using the definition and your monitoring of the model behavior, determine the areas of growth and decline of the function; 3) Determine how the slope tangent changes in these areas and at the point $\boldsymbol{E}$.

Task 2. Observe the behavior of the tangent to the curve and changes on the chart of the tangent to the tilt angle and find out: 1 ) how the function behaves when the slope tangent is positive; 2 ) how the function behaves when the slope tangent is negative; 3 ) formulate the theorem on the sufficient condition for growth (decay) of the function.

Task 3. Using the scroll bar, decrease the increments for $X$ to 0 and find out: 1 ) how the tangent looks at the point $E_{\text {; }}$ 2) what value the slope has; 3 ) recollect how the points are called, in which the derivative of the function (the tangent of the slope) is 0 or does not exist. Is the point $\mathbf{E}$ such a point? 4) formulate the Fermat's theorem and illustrate its proposition using the model (Fig. 3).
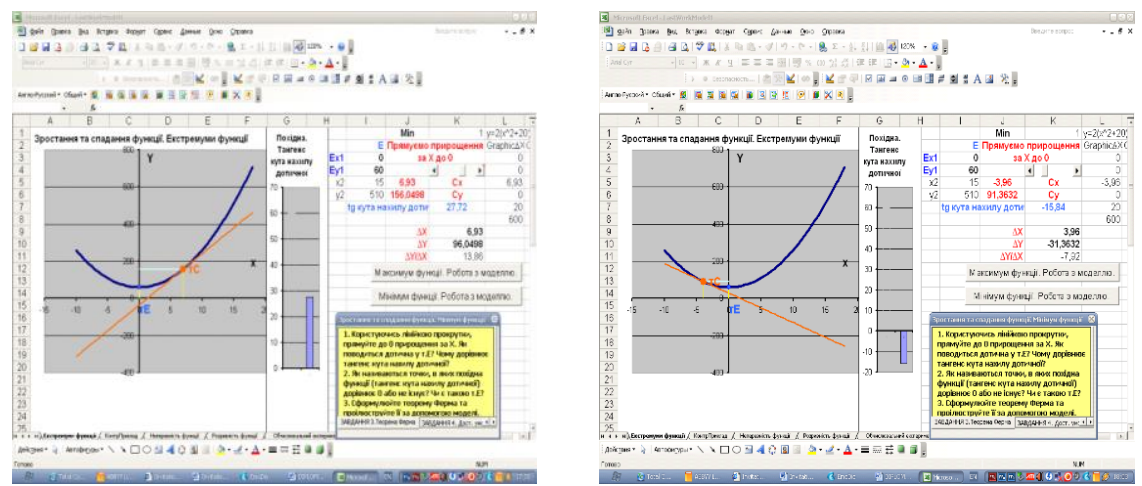

Fig. 3. The episodes of pupils' elaborating the task $\mathbf{3}$ with model "Extremums", illustrating the Fermat's theorem 
Model 8 allows students to hold computational experiment, based on the fact that the numerical approximated methods of derivative functions at a certain point can be calculated using finite differences. Didactic support of the model offers a plan for conducting approximate derivative calculations with different steps of the argument changing, and encourages students to observe how these values are gradually directed to the exact value of the derivative function at a point calculated analytically. The model enables students to change the parameters of the function and the coordinates of the point where the derivative is calculated. It allows the model to be extended to a wide range of functions. The results of the computational experiment provided by the Model 8 are given on the Figure 4.

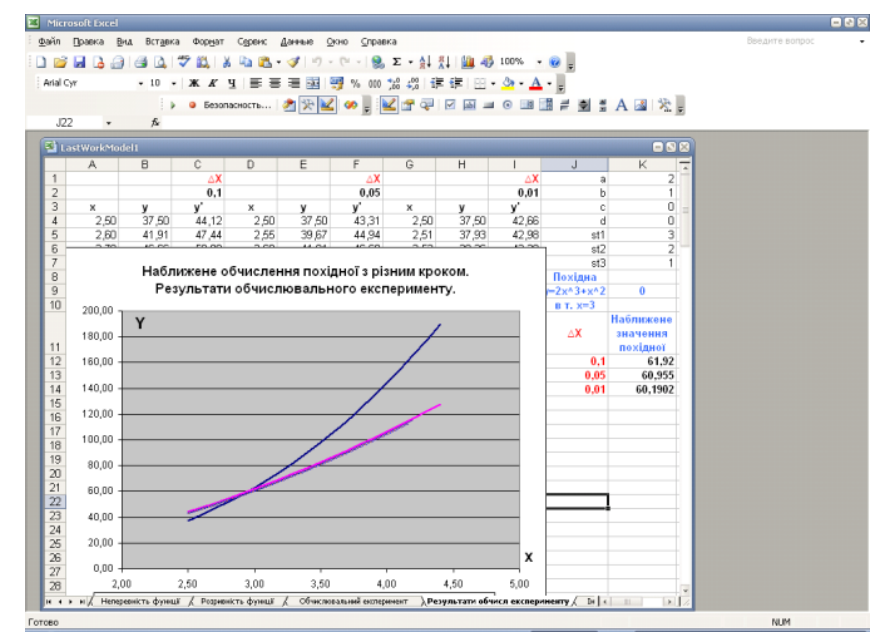

Fig. 4. The results of the computational experiment provided by the Model 8

Models 9-11 of the complex are devoted to the learning of a definite integral concept, its geometric interpretation, and exploration of its properties. In particular, the models of this group enable to Illustrate and realize the mechanistic interpretation of Newton-Leibniz's theorem. Selected moments of the models processing are given on the Fig.5.
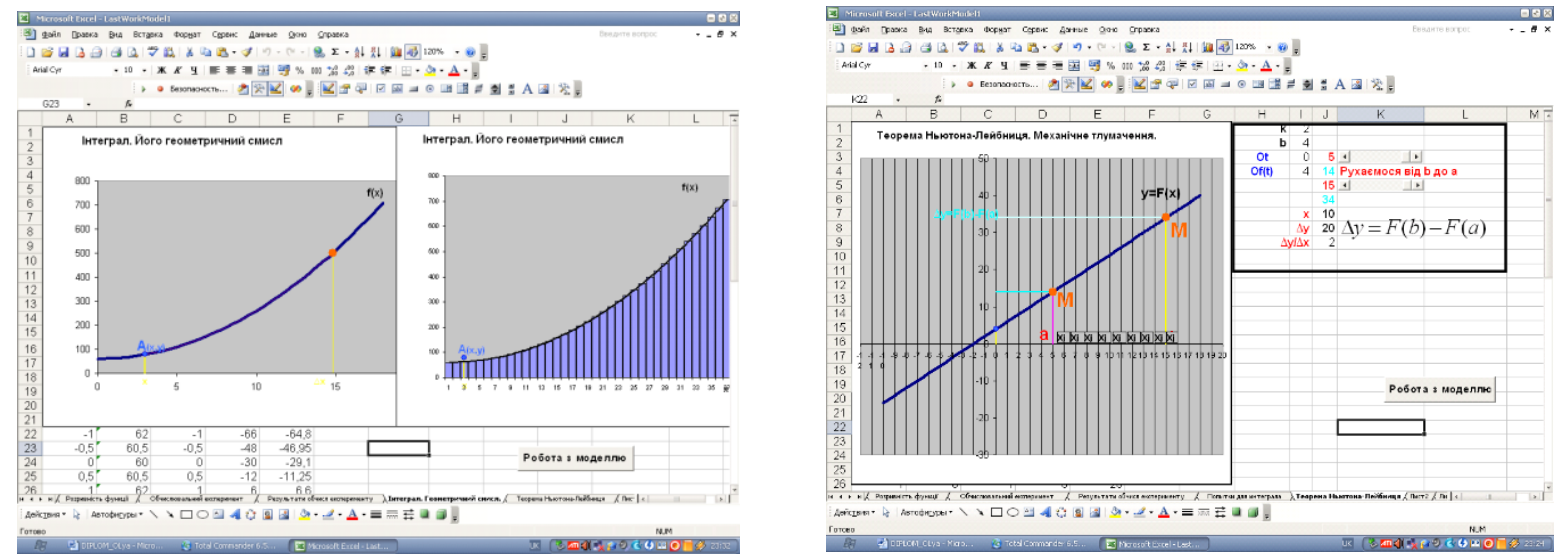

Fig. 5. Selected moments of the models 9-11 processing

\section{DISCUSSION}

On balance, characterizing represented complex of computer models, it is important to emphasize their potential as for their implementation in terms of holistic approach to Mathematics school learning. The key tasks of didactic support to all of the models stimulate the autonomy of trainees' thoughts and judgments which they obtain via active learning, which matches the main pillar of holistic education.

In addition, the elaborated models encourage trainees' mental activities and involve them into the reality of the cognitive situation. They enable students to obtain not only visual interpretation of abstract mathematical objects, but also to establish strong connections between concepts providing them with deep understanding how mathematical objects are linked to each other and how they match to the real objects. These characteristics testify that the models are able to contribute to holistic Mathematics learning.

Finally, the presented complex of models provides transdisciplinarity, as the activity with them gives trainees understanding how mathematical objects work together and how they unite non-mathematical subject areas.

Thus, the complex of computer models as for their functionality matches main principles of the holistic education, such as independent cognitive activity, connections establishing, focus on the ruining boundaries between subject fields and reality.

\section{CONCLUSIONS}

In accordance with the purpose of the paper, the authors' complex of computer models and their didactic facilities as for the abstract mathematical concepts mastering by schoolchildren is represented. All groups of the models are characterized along with the examples of their classroom using in terms of holistic approach to school Mathematics learning. Their holistic potential 
is covered. It seems to be relevant to predict positive influence of the computer models implementation on the forming of trainees' holistic system of knowledge and skills. Elaboration of proper methodology of its diagnosing and estimation might be a prospect of our further research.

\section{References}

1. Brinkmann, A. (2001). Mathematical Networks - Conceptual Foundation and Graphical Representation, in: R. Soro (ed.), Current State of Research on Mathematical Beliefs X, Proceedings of the MAVI-10 European Workshop in Kristianstad, Sweden, June 2-5, 2001, University of Turku, Department of Teacher Education, Pre-Print nr. 1, 7-16.

2. Concept of the New Ukrainian School, Retrieved from www.nus.org.ua [in Ukrainian]

3. Curriculum for the 10-11 grades of secondary learning establishments. Mathematics. Retrieved from: https://mon.gov.ua/ua/osvita/zagalna-serednya-osvita/navchalni-programi/navchalni-programi-dlya-10-11-klasiv

4. Gusev, V. A. (2010). Theoretical foundations of teaching mathematics in secondary school : book for universities. M. : Drofa [In Russian].

5. Hejný, M. (2002). Creating Mathematical Structure. In: Novotná, J. (ed.): European Research in Mathematics Education II, Charles University Prague, 14-24.

6. Hejný, M. (2003). Understanding and Structure. In CERME3 (Conference on European Research in Mathematics Education 3, Group 11), Feb. 28 - March 3, Bellaria, Italy, Retrieved from http://www.dm.unipi.it/ didattica/CERME3.

7. Hejný, M. (2005). From experience, through generic models to abstract knowledge, In CERME4 (Conference on European Research in Mathematics Education 4, Group 3), Retrieved from http://www.mathematik.unidortmund.de/ erme/CERME4/CERME4_WG3.pdf.

8. Mahmoudi, S., Jafari, E., Nasrabadi, H., Liaghatdar, M. (2012). Holistic Education: An Approach for 21 Century. International Education Studies, v5, n2, 178-186.

9. Miller, J. (2005). Holistic learning and spirituality in education: Breaking new ground. Albany: State University of New York Press. New York Press Ed.

10. Rakov, S. (2005). Mathematical education: competence approach with ICT using: Monograph. Kh.: Fact. [In Ukrainian].

11. Semenikhina, O. (2014). GeoGebra 5.0 tools and their use during problems solving. Information technologies and learning tools, 44 (6), 124-133 [in Ukrainian].

12. Shamshina, N. (2018). Solving Tasks Of Computer Modeling In Excel Spreadsheet. Physical and Mathematical Education. 4(18). 171-176.

13. Singh, K. (1996). Education for the Global Society', in Learning: The Treasure Within, The Report to UNESCO of the International Commission on Education for the Twenty First Century, Paris: UNESCO.

14. Ubiratan D'Ambrosio (1981). Uniting Reality and Action: A Holistic Approach to Mathematics Education L. A. Steen et al. (eds.), Teaching Teachers, Teaching Students. - Springer Science+Business Media New York. 33-42.

15. Markova, I.S. (2007). Urok matematyky v suchusnyh tehnologiyah: troria I practyca. Kh.: «Osnova»: «Triada+» [in Ukrainian].

\section{ВИКОРИСТАННЯ КОМПЮТЕРНИХ МОДЕЛЕЙ В УМОВАХ РЕАЛІЗАЦІЇ ЦІЛІСНОГО ПІДХОДУ ДО НАВЧАННЯ МАТЕМАТИКИ В ШКОЛ \\ Л.І. Білоусова, Л.Е. Гризун}

Харківський національний педагогічний університет імені Г.С. Сковороди, Україна

Анотація. Аналіз проблем сучасної математичної освіти свідчить про необхідність удосконалення підходів до навчання. Математика сьогодні, як складна інтегрована наука, прагне стати мостом між різними предметними областями, що викликає більшу важливість глибокого розуміння ії основ. 3 іншого боку, вивчення математики виявляється дуже складним для школярів, оскільки вона оперує системою понять з високим рівнем абстракції. Таким чином, згідно з дослідженнями, уявляється необхідним впровадження холістичних освітніх ідей у викладання математики в школі. Це може допомогти срормувати у школярів концентровані концептуальні математичні знання та полегшити їх використання.

Формулювання проблеми. Однак, щоб ерективно застосовувати цілісний підхід, ми повинні озброїти вчителів належними дидактичними засобами. Зважаючи на вищевикладене, розробка комп'ютерних моделей та їх впровадження для цілісного вивчення математичних об'єктів стають актуальними для сучасної освіти. Метою статті є представлення авторського комплексу комп'ютерних моделей та їх дидактичної підтримки щодо опанування школярами абстрактних математичних понять. Висвітлюється також роль моделей та рекомендацій для їх використання з точки зору цілісного підходу до вивчення математики в школі.

Матеріали і методи. Аналіз низки досліджень дає змогу сформулювати теоретичні основи щодо особливостей оволодіння студентами математичними об'єктами, а також з'ясувати труднощі, які можуть виникнути під час навчання, та запропонувати інструменти для їх подолання. У ході дослідження застосовано набір теоретичних, емпіричних та моделюючих методів. Теоретичним підгрунтям розробки комп'ютерних моделей є комплексний аналіз чинної навчальної програми з математики, вимоги до кінцевих вимог до знань учнів, а також вивчення відповідних предметних областей, які автори провели заздалегідь. Для того, щоб вдовольнити основні принципи цілісного підходу до математичної освіти, необхідно також виявити ключові математичні об'єкти, встановити зв'язки між ними, побудувати ланцюги належних внутрішніх і трансдисциплінарних зв'язків.

Результати. Результати теоретичного аналізу були використані при розробці авторського комплексу комп'ютерних моделей, які доцільно застосовувати в умовах реалізації цілісного підходу до навчання математики в школі. Комплекс охоплює кілька груп моделей, спрямованих на полегшення освоєння ряду абстрактних математичних понять. Висвітлено процес розробки моделей, їх функціонал та дидактичну підтримку. Обгрунтовано та проаналізовано потенціал розробленого комплексу комп'ютерних моделей щодо їх реалізації в умовах цілісного підходу до вивчення математики в школі.

Висновки та перспективи подальшого дослідження. Уявляється можним очікувати позитивний вплив впровадження комп'ютерних моделей на формування цілісної системи знань і навичок учнів. Розробку належної методики ї̈ діагностування та оцінки слід віднести до перспектив подальшого дослідження.

Ключові слова: цілісний підхід, математична освіта, комп'ютерні моделі, навчання математики в школі, оволодіння абстрактними поняттями, дидактичні можливості комп'ютерних моделей. 